\title{
Efficacy of Axitinib After Nivolumab Failure in Metastatic Renal Cell Carcinoma
}

\author{
HIROKI ISHIHARA ${ }^{1}$, TOSHIO TAKAGI ${ }^{1}$, TSUNENORI KONDO ${ }^{2}$, HIRONORI FUKUDA ${ }^{1}$, \\ HIDEKAZU TACHIBANA ${ }^{2}$, KAZUHIKO YOSHIDA ${ }^{1}$, JUNPEI IIZUKA ${ }^{1}$, \\ MASAYOSHI OKUMI ${ }^{1}$, HIDEKI ISHIDA $^{1}$ and KAZUNARI TANABE ${ }^{1}$ \\ ${ }^{1}$ Department of Urology, Tokyo Women's Medical University, Tokyo, Japan; \\ ${ }^{2}$ Department of Urology, Tokyo Women's Medical University Medical Center East, Tokyo, Japan
}

\begin{abstract}
Background/Aim: Whether molecular-targeted therapy, particularly axitinib, is effective after failure of immune checkpoint inhibitors in metastatic renal cell carcinoma $(m R C C)$ remains unclear. Here, we evaluated the therapeutic effect of axitinib as a third-line therapy following second-line nivolumab monotherapy for $m R C C$. Patients and Methods: Data from patients treated with axitinib as a thirdline therapy after failure of first-line tyrosine kinase inhibitor (TKI) and second-line nivolumab monotherapy were reviewed. The progression-free survival (PFS), overall survival (OS), and objective response rate during axitinib therapy were retrospectively evaluated. Tumor responses were assessed according to the Response Evaluation Criteria in Solid Tumors version 1.1. Results: Seventeen patients were treated with third-line axitinib after failure of prior TKI and nivolumab. During a median follow-up of 8.15 months, eight $(47.1 \%)$ and three (17.6\%) patients showed disease progression and died, respectively. The median PFS was 12.8 months [95\% confidence interval=(CI)4.08-21.7], the 1-year PFS rate was $51.3 \%$, and the 1-year OS rate was $71.6 \%$. The median magnitude of maximum changes of targeted lesions from baseline was $-11.9 \%$ (95\% CI=-36.1-0.44\%). The objective response rate and disease control rates were $29.4 \%$ $(n=5)$ and $94.1 \%(n=16)$, respectively. Univariate analysis for PFS showed a shorter PFS in patients with non-clear cell histopathological types or those with liver metastases ( $p$ Value $<0.0001$ for both). Conclusion: Axitinib as a third-line
\end{abstract}

This article is freely accessible online.

Correspondence to: Tsunenori Kondo, Department of Urology, Tokyo Women's Medical University Medical Center East, 2-1-10 Nishiogu, Arakawa-ku, Tokyo 116-8567, Japan. Tel: +81 338101111, Fax: +81 358556319, e-mail: kondo.tsunenori@twmu.ac.jp

Key Words: RCC, ICI, targeted therapy, PD-1, PD-L1, subsequent therapy. therapy showed reasonable therapeutic efficacy after the failure of first-line TKI and second-line nivolumab monotherapy for mRCC. Further studies are needed to confirm our findings.

Systemic therapy strategies for metastatic renal cell carcinoma (mRCC) have been dramatically changed in recent years with the development of immune checkpoint inhibitors (ICIs) (1). These agents have been evaluated in clinical trials, and this paradigm shift is expected to continue (2). Based on previous trials $(3,4)$, current guidelines recommend combined regimens consisting of ICIs with different modes of action (e.g., targeting different molecules, such as PD-1, PD-L1, or CTLA-4) or ICI plus molecular-targeted therapy as first-line therapy (5). However, the efficacy of subsequent targeted therapy following the failure of ICIs (and combinative targeted therapy) is not well-understood.

Previously, reasonable efficacy of subsequent targeted therapy as second- or later-line therapy after the failure of ICIs was reported in mRCC (6-10). However, these studies were conducted in cohorts of patients with heterogeneous lines, classes of targeted therapy or classes of prior ICIs. Therefore, this heterogeneity may have biased the results. Axitinib, a second-generation vascular endothelial growth factor receptor (VEGFR)-tyrosine kinase inhibitor (TKI), was approved as second-line therapy for previously treated $\mathrm{mRCC}$ based on the findings of the AXIS trial (11). Additionally, in some cases, axitinib administration has been considered as a later-line targeted therapy (5). Under current guidelines, patients classified as intermediate or of poor risk are recommended for administration of combinative ipilimumab plus nivolumab as first-line therapy (5). Thus, second- or later-line axitinib therapy following ICIs is expected to increase. However, the efficacy of targeted therapy, particularly of axitinib, after the failure of ICIs, remains unclear.

We have previously reported the potential utility of axitinib after nivolumab in six patients as a case series study (12). In this study, using our extended data, we evaluated the 
in vivo $34: 1541-1546(2020)$

Table I. Patient characteristics.

\begin{tabular}{|c|c|}
\hline Variable & $\mathrm{N}(\%)$ \\
\hline \multicolumn{2}{|l|}{ Age } \\
\hline$\geq 65$ years & $11(64.7 \%)$ \\
\hline \multicolumn{2}{|l|}{ Sex } \\
\hline Male & $12(70.6 \%)$ \\
\hline \multicolumn{2}{|l|}{ Histopathology } \\
\hline Clear-cell carcinoma & $13(76.5 \%)$ \\
\hline \multicolumn{2}{|c|}{ IMDC risk at the initiation of axitinib } \\
\hline Favorable & $1(5.88 \%)$ \\
\hline Intermediate & $6(35.3 \%)$ \\
\hline Poor & $10(58.9 \%)$ \\
\hline \multicolumn{2}{|c|}{$\begin{array}{l}\text { Number of organs involving metastases } \\
\text { at the initiation of axitinib }\end{array}$} \\
\hline Multiple & $14(82.4 \%)$ \\
\hline \multicolumn{2}{|c|}{ Liver metastasis status at the initiation of axitinib } \\
\hline Presence & $3(17.6 \%)$ \\
\hline \multicolumn{2}{|l|}{ First-line targeted therapy } \\
\hline Sorafenib & $4(23.5 \%)$ \\
\hline Sunitinib & $7(41.2 \%)$ \\
\hline Pazopanib & $5(29.4 \%)$ \\
\hline Axitinib & $1(5.88 \%)$ \\
\hline \multicolumn{2}{|c|}{ Duration of first-line time to progression, months } \\
\hline Median (interquartile range) & $13.6(7.87-31.2)$ \\
\hline$\geq 12$ & $9(52.9 \%)$ \\
\hline \multicolumn{2}{|c|}{ Best tumor response during first-line therapy } \\
\hline Complete response & $3(17.6 \%)$ \\
\hline Partial response & $7(41.2 \%)$ \\
\hline Stable disease & $6(35.3 \%)$ \\
\hline Progressive disease & $1(5.88 \%)$ \\
\hline \multicolumn{2}{|c|}{ Duration of second-line time to progression, months } \\
\hline Median (interquartile range) & $4.27(2.81-7.05)$ \\
\hline$\geq 6$ & $5(29.4 \%)$ \\
\hline \multicolumn{2}{|c|}{ Best tumor response during second-line therapy } \\
\hline Complete response & 0 \\
\hline Partial response & $6(35.3 \%)$ \\
\hline Stable disease & $6(35.3 \%)$ \\
\hline Progressive disease & $5(29.4 \%)$ \\
\hline \multicolumn{2}{|l|}{ Duration of follow-up, months } \\
\hline Median (interquartile range) & $8.15(5.00-13.0)$ \\
\hline
\end{tabular}

IMDC: International Metastatic Renal Cell Carcinoma Database Consortium.

efficacy of third-line axitinib after the failure of first-line TKI and second-line nivolumab monotherapy. We evaluated the efficacy of axitinib in this unified regimen to reduce possible biases induced by heterogeneous lines or classes of drugs. This regimen is not preferentially recommended by the current guidelines (5); however, data describing the efficacy of axitinib after nivolumab may lead to improved treatments in this field.

\section{Patients and Methods}

Patient selection. Between June 2013 and October 2019, 46 patients were treated with at least one dose of nivolumab as a second-line monotherapy after the failure of first-line TKI for $\mathrm{mRCC}$ in our
Table II. Response to third-line axitinib.

\begin{tabular}{lc}
\hline Variable & $\mathrm{N}(\%)$ \\
\hline Objective response rate & $5(29.4 \%)$ \\
Disease control rate & $16(94.1 \%)$ \\
$\quad$ Complete response & 0 \\
Partial response & $5(29.4 \%)$ \\
Stable disease & $11(64.7 \%)$ \\
$\quad$ Progressive disease & $1(5.88 \%)$ \\
Magnitude of maximum change of targeted lesions & \\
from baseline & $-11.9(-36.1-0.44)$ \\
$\quad$ Median (interquartile range), $\%$ & $13(76.5 \%)$ \\
$>0 \%$ &
\end{tabular}

department and its affiliated institution. Thereafter, 30 patients showed disease progression after nivolumab, and 19 patients were further treated with axitinib as a third-line therapy. After excluding two patients without eligible clinical data, the remaining 17 patients were evaluated in this retrospective study. Among the 17 patients, three patients were examined in our previous case series study investigating the efficacy of subsequent axitinib after nivolumab (12).

The Internal Ethics Review Boards of the Tokyo Women's Medical University approved this study (ID: 5311), which was performed within the tenets of the Declaration of Helsinki. All clinical and laboratory data were extracted from an electronic database and patient medical records. Due to the retrospective observational nature of this study, the need for informed consent was waived.

Protocol of nivolumab therapy. Nivolumab (3 $\mathrm{mg} / \mathrm{kg}$ ) was intravenously administered every 2 weeks based on a previous pivotal trial (13). Dose modification was not allowed for any cases; however, the interval between administrations was modified according to the patient's condition.

Protocol of molecular-targeted therapy. As a first-line targeted therapy, sunitinib or pazopanib was mainly used in our institutions. Before the approval of sunitinib, sorafenib was used. Axitinib was mainly used as a second- or a later-line therapy for previously treated cases because Japanese insurance does not cover the usage of axitinib in the first-line setting. The administration of mammalian target of rapamycin inhibitors (mTORis) was considered only when nonresponse or intolerability of adverse events during a prior therapy with VEGFR-TKIs was observed. The detailed protocols of the administration of each agent have been previously described $(14,15)$.

Treatment evaluation. Post-treatment follow-up scans were obtained by plane or contrast computed tomography or magnetic resonance imaging of the chest, abdomen, and pelvis at regular 4-12-week intervals, depending on the patient's condition. Drugs were administered until either radiographic or clinical disease progression, or intolerable adverse events were observed. Radiographic evaluation of the treatment response was defined according to the Response Evaluation Criteria in Solid Tumors (RECIST) version 1.1 (16).

Statistical analysis. Progression-free survival (PFS) was calculated from the initiation of axitinib until progressive disease or death, whichever occurred first. Surviving patients without disease progression were censored at the time of the last follow-up. Overall survival (OS) 


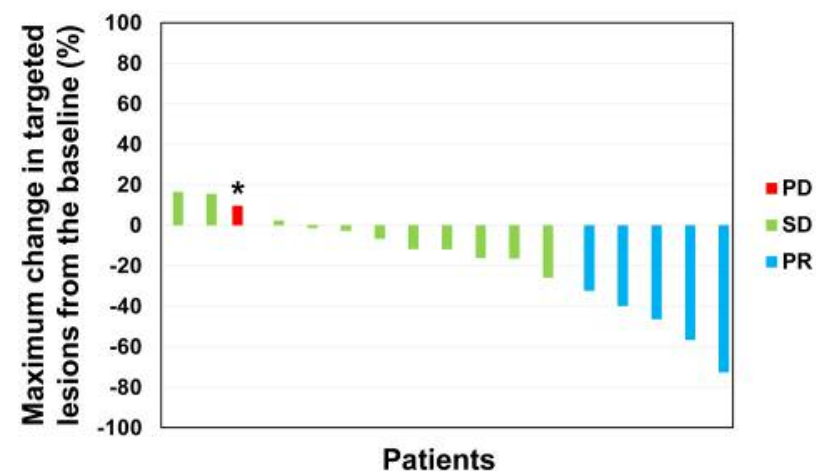

Figure 1. Waterfall plot for maximum changes of targeted lesions from baseline. *Patient whose best tumor response was diagnosed as progressive disease based on the RECIST v.1.1. because of the appearance of new lesions. PD: Progressive disease; SD: stable disease; PR: partial response.

was calculated from the initiation of axitinib until death from any cause. Patients lost to follow-up were censored at the time of last contact. Survival was calculated using the Kaplan-Meier method and compared using the log-rank test. Univariate analysis was conducted to identify risk factors for PFS. The risk was expressed as hazard ratios and $95 \%$ confidence intervals (CIs). All statistical analyses were conducted using the JMP software (version 14; SAS Institute, Inc., Cary, NC, USA) with a significance level of 0.05 ( $p$-Value $<0.05$ ).

\section{Results}

Patient characteristics. The characteristics of the 17 patients are shown in Table I. First-line TKI was discontinued in 16 patients due to disease progression and in one patient because of intolerable adverse events. For second-line therapy, nivolumab was discontinued because of disease progression in all patients. Based on the IMDC risk classification at the initiation of axitinib (17), one (5.88\%), $6(35.3 \%)$, and 10 $(58.9 \%)$ patients were classified into the favorable, intermediate, and poor risk categories, respectively. For firstline TKI, sunitinib was the most commonly administered drug $(\mathrm{n}=7,41.2 \%)$, followed by pazopanib $(\mathrm{n}=5,29.4 \%)$. The median follow-up duration was 8.15 months (interquartile range $=5.00-13.0$ ).

Tumor response to third-line axitinib. For third-line axitinib, a partial response, stable disease, and progressive disease based on RECIST version 1.1 were observed in 5 (29.4\%), $11(64.7 \%)$, and one (5.88\%) patients, respectively (Table II). The objective response rate and disease control rate were $29.4 \%(n=5)$ and $94.1 \%(n=16)$, respectively. The maximum changes in targeted lesions from baseline are individually presented in a waterfall plot (Figure 1). The median maximum change was $-11.9 \%(95 \% \mathrm{CI}=-36.1-0.44 \%)$, and $13(76.5 \%)$ patients exhibited tumor shrinkage (Table II).
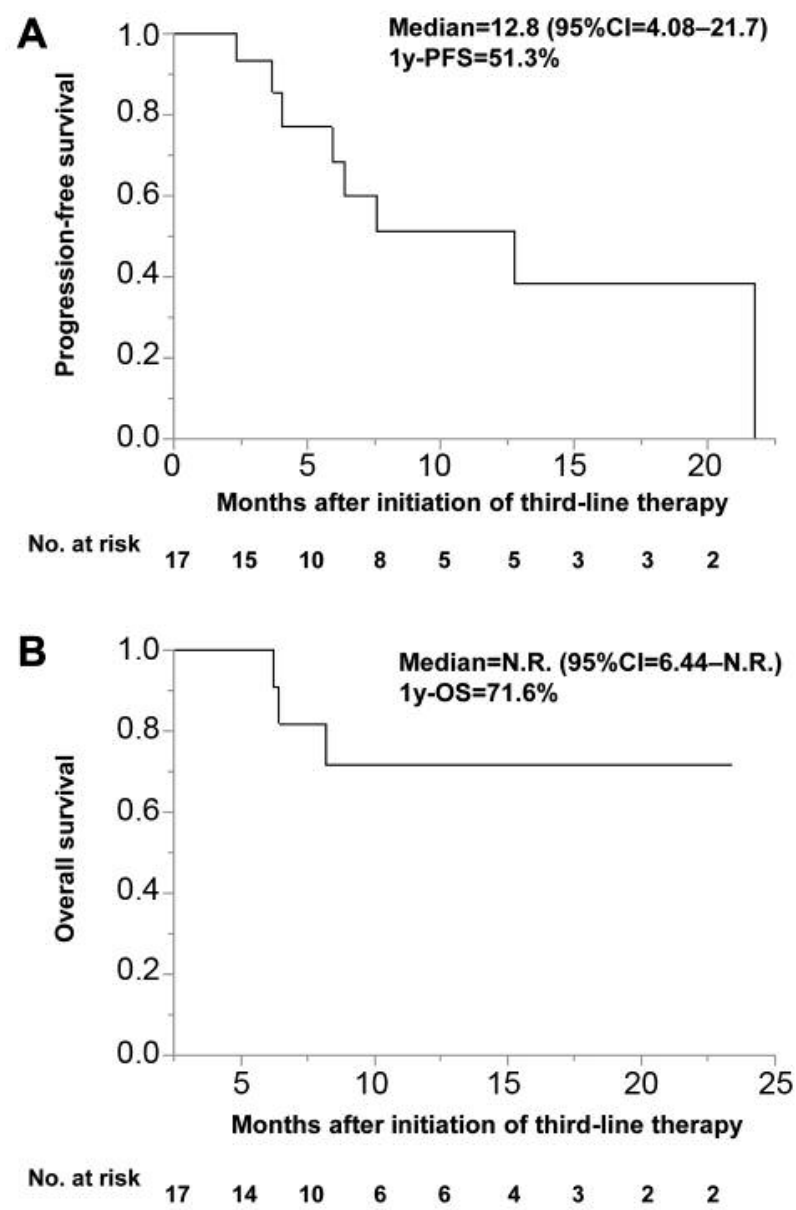

Figure 2. Progression-free and overall survival after the initiation of axitinib. CI: Confidence interval; N.R.: not reached; PFS: progressionfree survival; OS: overall survival.

Survival in third-line axitinib. During follow-up, 8 (47.1\%) and $3(17.6 \%)$ patients showed disease progression and died for any cause, respectively. The median PFS after the initiation of axitinib was 12.8 months $(95 \% \mathrm{CI}=4.08-21.7)$ and the 1 -year PFS rate was $51.3 \%$ (Figure 2). OS did not reach the median (95\%CI $=6.44-$ N.R.), and the 1 -year OS rate was $71.6 \%$.

Univariate analysis using the log-rank test in each category of variables was conducted (Table III). A shorter PFS was observed in patients with non-clear cell histopathological types [median=3.68; $(95 \% \mathrm{CI}=2.33-4.08) v s .17 .2(5.92-21.7)$ months, $p<0.0001]$ or those with liver metastases [median $=3.01 ; \quad(95 \% \mathrm{CI}=2.33-3.68) \quad v s .12 .8 \quad(4.08-21.7)$ months, $p<0.0001]$. Any other factors, including the duration of the response or magnitude of the tumor response in prior therapies, were not associated with PFS (all, $p>0.05$ ). Figure 3 illustrates the time of distinct systemic therapies in first-line TKI, second-line nivolumab, and third-line axitinib. This chart also shows that there was no correlation for the outcome between axitinib and prior therapies. 
Table III. Log-rank test for progression-free survival after the initiation of axitinib.

\begin{tabular}{|c|c|c|c|c|}
\hline Variable & Category & $\begin{array}{l}\text { Number of patients } \\
\text { Events/total }\end{array}$ & Median $(95 \% \mathrm{CI})$ & $p$-Value \\
\hline \multirow[t]{2}{*}{ Age, years } & $\geq 65$ & $4 / 11$ & 12.8 (3.68-N.R.) & 0.504 \\
\hline & $<65$ & $4 / 6$ & $5.92(2.33-21.7)$ & \\
\hline \multirow[t]{2}{*}{ Gender } & Male & $5 / 12$ & $21.7(3.68-21.7)$ & 0.241 \\
\hline & Female & $3 / 5$ & $6.38(4.08-12.8)$ & \\
\hline \multirow[t]{2}{*}{ Histopathology } & Clear-cell carcinoma & $5 / 13$ & $17.2(5.92-21.7)$ & $<0.0001$ \\
\hline & Non-clear cell carcinoma & $3 / 4$ & $3.68(2.33-4.08)$ & \\
\hline \multirow[t]{2}{*}{ IMDC risk at the initiation of axitinib } & Favorable/intermediate & $1 / 7$ & N.R. (6.38-N.R.) & 0.166 \\
\hline & Poor & $7 / 10$ & $7.59(2.33-21.7)$ & \\
\hline \multirow{2}{*}{$\begin{array}{l}\text { Number of organs involving metastases } \\
\text { at the initiation of axitinib }\end{array}$} & Multiple & $7 / 14$ & $7.59(3.68-21.7)$ & 0.465 \\
\hline & Single & $1 / 3$ & N.R. (12.8-N.R.) & \\
\hline \multirow[t]{2}{*}{ Liver metastasis status at the initiation of axitinib } & Presence & $2 / 3$ & $3.01(2.33-3.68)$ & $<0.0001$ \\
\hline & Absence & $6 / 14$ & $12.8(4.08-21.7)$ & \\
\hline \multirow[t]{2}{*}{ Duration of first-line time to progression, months } & $\geq 12$ & $5 / 9$ & $6.38(3.68-12.8)$ & 0.273 \\
\hline & $<12$ & $3 / 8$ & $21.7(2.33-21.7)$ & \\
\hline \multirow[t]{2}{*}{ Best tumor response during first-line therapy } & Responder* & $2 / 10$ & N.R. (3.68-N.R.) & 0.139 \\
\hline & Non-responder & $6 / 7$ & $6.76(2.33-21.7)$ & \\
\hline \multirow[t]{2}{*}{ Duration of second-line time to progression, months } & $\geq 6$ & $2 / 5$ & 6.38 (5.92-N.R.) & 0.915 \\
\hline & $<6$ & $6 / 12$ & $12.8(3.68-21.7)$ & \\
\hline \multirow[t]{2}{*}{ Best tumor response during second-line therapy } & Responder* & $2 / 6$ & $6.15(5.92-6.38)$ & 0.247 \\
\hline & Non-responder & $6 / 11$ & $12.8(3.68-21.7)$ & \\
\hline
\end{tabular}

CI: Confidence interval; IMDC: International Metastatic Renal Cell Carcinoma Database Consortium; N.R.: not reached. *Responder was defined as a patient whose best tumor response was partial or complete response during therapy.

\section{Discussion}

This retrospective study revealed the reasonable efficacy of axitinib as a third-line therapy after the failure of a first-line VEGFR-TKI and a second-line nivolumab monotherapy for mRCC. The median PFS was 12.8 months, and the 1 -year OS rate was $71.6 \%$. Additionally, $76.5 \%$ of patients presented with tumor shrinkage, and the objective response and disease control rates were $29.4 \%$ and $94.1 \%$, respectively. Furthermore, based on univariate analysis, the non-clear cell histopathological type and presence of liver metastases were associated with a shorter PFS. This extended analysis supports our previous findings in terms of the benefit of subsequent axitinib following ICIs (12).

The feasible anti-tumor effect of targeted therapy following ICIs has been previously reported in $\mathrm{mRCC}$ (610). Albiges et al. have reported that the median time to treatment failure for subsequent targeted therapy after ICIs was 6.6 months, and the 1 -year OS rate was $58 \%$ (6). Nadal et al. have reported that the median PFS with subsequent TKIs after ICIs was 6.4 months, and the objective response rate was $28 \%$ (7). These data were obtained from previous clinical trials, and axitinib was the most common agent used in their cohorts in $35.7 \%$ (6) and $67.1 \%$ of patients (7), respectively. Furthermore, Cao et al. have recently reported that subsequent pazopanib shows an encouraging efficacy; the median PFS was 13.5 months, and the 1-year OS rate

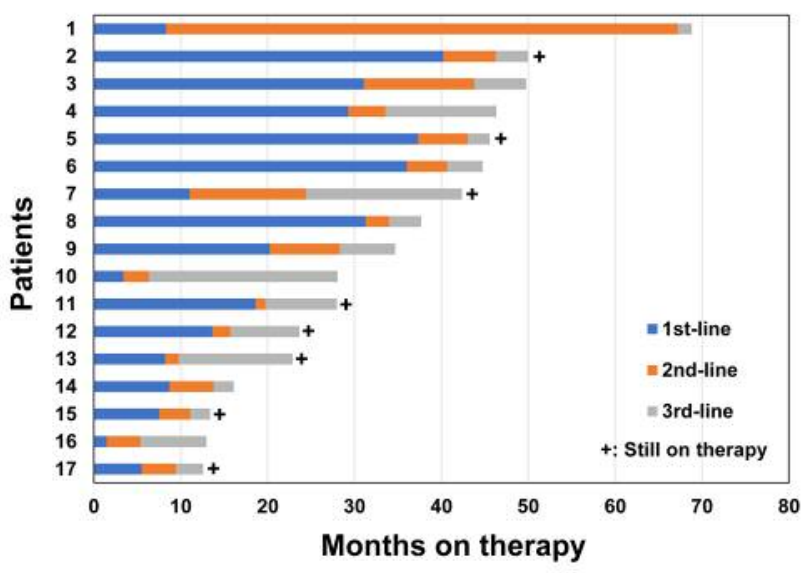

Figure 3. Timing and duration of distinct systemic therapies in first-line tyrosine kinase inhibitors, second-line nivolumab, and third-line axitinib.

was $89 \%$, according to their real-world data (8). In the current study, we evaluated the efficacy of axitinib administration after ICIs using a unified regimen to reduce possible biases induced by the heterogeneity of lines or classes of targeted therapy or classes of prior ICIs. Our findings are generally consistent with previous findings.

In the targeted therapy era, the AXIS trial observed a median PFS of 6.7 months and an objective response rate of $19.0 \%$ following second-line therapy (11). Moreover, third- 
line targeted therapy after the failure of prior targeted therapies (e.g., TKI-TKI-mTORi or TKI-mTORi-TKI) achieved a median PFS of 3.7-3.9 months and an objective response rate of $3.9-10.4 \%(18,19)$. Another study showed that the median OS after third-line initiation was 13.8 months, and the 1 -year OS rate was $54 \%$ (20). Additionally, in a previous study by our group, the median PFS and OS after third-line initiation following prior targeted therapies were 2.76 and 8.71 months, respectively, and the objective response rate was $18.2 \%$ (15). Taken together, although it is difficult to directly compare the findings between the present study and previous ones, the efficacy of axitinib after nivolumab appears to be superior despite its usage as a "later", third-line therapy.

Finally, several factors identified in the targeted therapy era $(21,22)$ appear to be associated with survival when axitinib is administered after ICIs. Thus, even after ICI administration, these predictive factors may be useful in a subsequent targeted therapy. We observed no association in outcomes between third-line axitinib and prior therapies in our analysis. However, Auvray et al. have reported that PFS in second-line targeted therapy after first-line ICIs was significantly longer in patients with a long first-line duration of response (9). Furthermore, a positive correlation in outcomes between first- and second-line targeted therapies has been previously reported $(14,23,24)$; however, further studies are required to determine the correlation of outcomes among each line in sequential therapy, including ICIs.

This study has several limitations. First, because this was a retrospective study conducted in two centers with a small sample size, biases of patient or drug selection could not be avoided. Furthermore, because of the limited number of events, we conducted only univariate analyses for PFS to analyze risk factors. Second, the relatively shorter duration of follow-up may have affected the interpretation of the outcome analyses. Third, the irregular interval of radiographic examinations may have introduced biases in the analyses.

In conclusion, this retrospective study revealed the reasonable therapeutic efficacy of axitinib as a third-line targeted therapy after the failure of first-line TKI and second-line nivolumab monotherapy in mRCC. Further studies are needed to confirm our findings.

\section{Conflicts of Interest}

Tsunenori Kondo received honoraria from Pfizer and Ono Pharmaceutical. All other authors have no conflicts of interest to declare.

\section{Authors' Contributions}

Hiroki Ishihara, Toshio Takagi, and Tsunenori Kondo designed the study. Hiroki Ishihara, Toshio Takagi, and Tsunenori Kondo interpreted the data and wrote the manuscript. Toshio, Takagi,
Tsunenori Kondo, Hironori Fukuda, Hidekazu Tachibana, Kazuhiko Yoshida, Junpei Iizuka, Masayoshi Okumi, Hideki Ishida, and Kazunari Tanabe collected the data.

\section{Acknowledgements}

The Authors thank Ms. Nobuko Hata (Department of Urology, Tokyo Women's Medical University and Department of Urology) for secretarial work and Dr. Ryo Ishiyama (Department of Urology, Saiseikai Kurihashi Hospital) for collecting patient data.

\section{References}

1 Salgia NJ, Dara Y, Bergerot P, Salgia M and Pal SK: The changing landscape of management of metastatic renal cell carcinoma: Current treatment options and future directions. Curr Treat Options Oncol 20(5): 41, 2019. PMID: 30937639. DOI: 10.1007/s11864-019-0638-1

2 Loo V, Salgia M, Bergerot P, Philip EJ and Pal SK: First-line systemic therapy for metastatic clear-cell renal cell carcinoma: Critical appraisal of emerging options. Target Oncol, 2019. PMID: 31595385. DOI: 10.1007/s11523-019-00676-y

3 Motzer RJ, Tannir NM, McDermott DF, Aren Frontera O, Melichar B, Choueiri TK, Plimack ER, Barthelemy P, Porta C, George S, Powles T, Donskov F, Neiman V, Kollmannsberger CK, Salman P, Gurney H, Hawkins R, Ravaud A, Grimm MO, Bracarda S, Barrios CH, Tomita Y, Castellano D, Rini BI, Chen AC, Mekan S, McHenry MB, Wind-Rotolo M, Doan J, Sharma P, Hammers HJ and Escudier B: Nivolumab plus ipilimumab versus sunitinib in advanced renal-cell carcinoma. N Engl J Med 378(14): 1277-1290, 2018. PMID: 29562145. DOI: 10.1056/NEJMoa1712126

4 Rini BI, Plimack ER, Stus V, Gafanov R, Hawkins R, Nosov D, Pouliot F, Alekseev B, Soulieres D, Melichar B, Vynnychenko I, Kryzhanivska A, Bondarenko I, Azevedo SJ, Borchiellini D, Szczylik C, Markus M, McDermott RS, Bedke J, Tartas S, Chang YH, Tamada S, Shou Q, Perini RF, Chen M, Atkins MB and Powles T: Pembrolizumab plus axitinib versus sunitinib for advanced renal-cell carcinoma. N Engl J Med 380(12): 11161127, 2019. PMID: 30779529. DOI: 10.1056/NEJMoa1816714

5 Albiges L, Powles T, Staehler M, Bensalah K, Giles RH, Hora M, Kuczyk MA, Lam TB, Ljungberg B, Marconi L, Merseburger AS, Volpe A, Abu-Ghanem Y, Dabestani S, Fernandez-Pello S, Hofmann F, Kuusk T, Tahbaz R and Bex A: Updated european association of urology guidelines on renal cell carcinoma: Immune checkpoint inhibition is the new backbone in first-line treatment of metastatic clear-cell renal cell carcinoma. Eur Urol 76(2): 151156, 2019. PMID: 31151678. DOI: 10.1016/j.eururo.2019.05.022

6 Albiges L, Fay AP, Xie W, Krajewski K, McDermott DF, Heng DY, Dariane C, DeVelasco G, Lester R, Escudier B and Choueiri TK: Efficacy of targeted therapies after pd-1/pd-11 blockade in metastatic renal cell carcinoma. Eur J Cancer 51(17): 2580-2586, 2015. PMID: 26346135. DOI: 10.1016/j.ejca.2015.08.017

7 Nadal R, Amin A, Geynisman DM, Voss MH, Weinstock M, Doyle J, Zhang Z, Viudez A, Plimack ER, McDermott DF, Motzer R, Rini B and Hammers HJ: Safety and clinical activity of vascular endothelial growth factor receptor (vegfr)-tyrosine kinase inhibitors after programmed cell death 1 inhibitor treatment in patients with metastatic clear cell renal cell carcinoma. Ann Oncol 27(7): 1304-1311, 2016. PMID: 27059553. DOI: $10.1093 /$ annonc/mdw 160 
8 Cao X, Tang D, Ratto B, Poole A, Ravichandran S, Jin L, Gao W, Swallow E and Vogelzang NJ: Real-world clinical outcomes of pazopanib immediately after discontinuation of immunotherapy for advanced renal cell carcinoma. Clin Genitourin Cancer, 2019. PMID: 31727510. DOI: 10.1016/j.clgc.2019.10.010

9 Auvray M, Auclin E, Barthelemy P, Bono P, Kellokumpu-Lehtinen P, Gross-Goupil M, De Velasco G, Powles T, Mouillet G, Vano YA, Gravis G, Mourey L, Priou F, Rolland F, Escudier B and Albiges $\mathrm{L}$ : Second-line targeted therapies after nivolumab-ipilimumab failure in metastatic renal cell carcinoma. Eur J Cancer 108: 3340, 2019. PMID: 30616146. DOI: 10.1016/j.ejca.2018.11.031

10 Shah AY, Kotecha RR, Lemke EA, Chandramohan A, Chaim JL, Msaouel P, Xiao L, Gao J, Campbell MT, Zurita AJ, Wang J, Corn PG, Jonasch E, Motzer RJ, Sharma P, Voss MH and Tannir NM: Outcomes of patients with metastatic clear-cell renal cell carcinoma treated with second-line vegfr-tki after first-line immune checkpoint inhibitors. Eur J Cancer 114: 67-75, 2019. PMID: 31075726. DOI: 10.1016/j.ejca.2019.04.003

11 Rini BI, Escudier B, Tomczak P, Kaprin A, Szczylik C, Hutson TE, Michaelson MD, Gorbunova VA, Gore ME, Rusakov IG, Negrier S, Ou YC, Castellano D, Lim HY, Uemura H, Tarazi J, Cella D, Chen C, Rosbrook B, Kim S and Motzer RJ: Comparative effectiveness of axitinib versus sorafenib in advanced renal cell carcinoma (axis): A randomised phase 3 trial. Lancet 378(9807): 1931-1939, 2011. PMID: 22056247. DOI: 10.1016/s0140-6736(11)61613-9

12 Yoshida K, Takagi T, Kondo T, Kobayashi H, Iizuka J, Fukuda $\mathrm{H}$, Ishihara $\mathrm{H}$, Okumi $\mathrm{M}$, Ishida $\mathrm{H}$ and Tanabe $\mathrm{K}$ : Efficacy of axitinib in patients with metastatic renal cell carcinoma refractory to nivolumab therapy. Jpn J Clin Oncol 49(6): 576580, 2019. PMID: 30924496. DOI: 10.1093/jjco/hyz040

13 Motzer RJ, Escudier B, McDermott DF, George S, Hammers HJ, Srinivas S, Tykodi SS, Sosman JA, Procopio G, Plimack ER, Castellano D, Choueiri TK, Gurney H, Donskov F, Bono P, Wagstaff J, Gauler TC, Ueda T, Tomita Y, Schutz FA, Kollmannsberger C, Larkin J, Ravaud A, Simon JS, Xu LA, Waxman IM and Sharma P: Nivolumab versus everolimus in advanced renal-cell carcinoma. N Engl J Med 373(19): 18031813, 2015. PMID: 26406148. DOI: 10.1056/NEJMoa1510665

14 Ishihara H, Kondo T, Yoshida K, Omae K, Takagi T, Iizuka J and Tanabe K: Time to progression after first-line tyrosine kinase inhibitor predicts survival in patients with metastatic renal cell carcinoma receiving second-line molecular-targeted therapy. Urol Oncol 35(9): 542.e541-542.e549, 2017. PMID: 28619633. DOI: 10.1016/j.urolonc.2017.05.014

15 Ishihara H, Takagi T, Kondo T, Tachibana H, Yoshida K, Omae $\mathrm{K}$, Iizuka J, Kobayashi $\mathrm{H}$ and Tanabe K: Efficacy and safety of third-line molecular-targeted therapy in metastatic renal cell carcinoma resistant to first-line vascular endothelial growth factor receptor tyrosine kinase inhibitor and second-line therapy. Int J Clin Oncol 23(3): 559-567, 2018. PMID: 29327159. DOI: $10.1007 / \mathrm{s} 10147-018-1241-3$

16 Eisenhauer EA, Therasse P, Bogaerts J, Schwartz LH, Sargent D, Ford R, Dancey J, Arbuck S, Gwyther S, Mooney M, Rubinstein L, Shankar L, Dodd L, Kaplan R, Lacombe D and Verweij J: New response evaluation criteria in solid tumours: Revised recist guideline (version 1.1). Eur J Cancer 45(2): 228247, 2009. PMID: 19097774. DOI: 10.1016/j.ejca.2008.10.026
17 Ko JJ, Xie W, Kroeger N, Lee JL, Rini BI, Knox JJ, Bjarnason GA, Srinivas S, Pal SK, Yuasa T, Smoragiewicz M, Donskov F, Kanesvaran R, Wood L, Ernst DS, Agarwal N, Vaishampayan UN, Rha SY, Choueiri TK and Heng DY: The international metastatic renal cell carcinoma database consortium model as a prognostic tool in patients with metastatic renal cell carcinoma previously treated with first-line targeted therapy: A populationbased study. Lancet Oncol 16(3): 293-300, 2015. PMID: 25681967. DOI: $10.1016 / \mathrm{s} 1470-2045(14) 71222-7$

18 Wells JC, Stukalin I, Norton C, Srinivas S, Lee JL, Donskov F, Bjarnason GA, Yamamoto H, Beuselinck B, Rini BI, Knox JJ, Agarwal N, Ernst DS, Pal SK, Wood LA, Bamias A, Alva AS, Kanesvaran R, Choueiri TK and Heng DY: Third-line targeted therapy in metastatic renal cell carcinoma: Results from the international metastatic renal cell carcinoma database consortium. Eur Urol 71(2): 204-209, 2017. PMID: 27318422. DOI: $10.1016 /$ j.eururo.2016.05.049

19 Busch J, Seidel C, Erber B, Issever AS, Hinz S, Kempkensteffen C, Magheli A, Miller K, Grunwald V and Weikert S: Retrospective comparison of triple-sequence therapies in metastatic renal cell carcinoma. Eur Urol 64(1): 62-70, 2013. PMID: 22999519. DOI: 10.1016/j.eururo.2012.09.004

20 Iacovelli R, Farcomeni A, Sternberg CN, Carteni G, Milella M, Santoni M, Cerbone L, Di Lorenzo G, Verzoni E, Ortega C, Sabbatini R, Ricotta R, Messina C, Lorusso V, Atzori F, De Vincenzo F, Sacco C, Boccardo F, Valduga F, Massari F, Baldazzi V, Cinieri S, Mosca A, Maria Ruggeri E, Berruti A and Procopio G: Prognostic factors in patients receiving third line targeted therapy for metastatic renal cell carcinoma. J Urol 193(6): 19051910, 2015. PMID: 25433306. DOI: 10.1016/j.juro.2014.11.092

$21 \mathrm{Li} \mathrm{H}$, Samawi H and Heng DY: The use of prognostic factors in metastatic renal cell carcinoma. Urol Oncol 33(12): 509-516, 2015. PMID: 26359719. DOI: 10.1016/j.urolonc.2015.08.003

22 Heng DY, Choueiri TK, Rini BI, Lee J, Yuasa T, Pal SK, Srinivas S, Bjarnason GA, Knox JJ, Mackenzie M, Vaishampayan UN, Tan MH, Rha SY, Donskov F, Agarwal N, Kollmannsberger C, North S and Wood LA: Outcomes of patients with metastatic renal cell carcinoma that do not meet eligibility criteria for clinical trials. Ann Oncol 25(1): 149-154, 2014. PMID: 24356626. DOI: 10.1093/annonc/mdt492

23 Escudier B, Michaelson MD, Motzer RJ, Hutson TE, Clark JI, Lim HY, Porfiri E, Zalewski P, Kannourakis G, Staehler M, Tarazi J, Rosbrook B, Cisar L, Hariharan S, Kim S and Rini BI: Axitinib versus sorafenib in advanced renal cell carcinoma: Subanalyses by prior therapy from a randomised phase iii trial. Br J Cancer 110(12): 2821-2828, 2014. PMID: 24823696. DOI: 10.1038/bjc.2014.244

24 Elaidi R, Harbaoui A, Beuselinck B, Eymard JC, Bamias A, De Guillebon E, Porta C, Vano Y, Linassier C, Debruyne PR, GrossGoupil M, Ravaud A, Aitelhaj M, Marret G and Oudard S: Outcomes from second-line therapy in long-term responders to first-line tyrosine kinase inhibitor in clear-cell metastatic renal cell carcinoma. Ann Oncol 26(2): 378-385, 2015. PMID: 25467013. DOI: $10.1093 /$ annonc/mdu552

Received March 9, 2020

Revised March 21, 2020

Accepted March 24, 2020 